\title{
Women Entrepreneurship In Nigeria: Drivers, Barriers And Coping Strategies
}

\author{
Chijioke NWACHUKWU' ${ }^{1}$, Olatunji FADEYI ${ }^{2}$, Njoku PAUL $^{3}$, Hieu Minh VU 4 \\ \{cesogwa@yahoo.com¹, fadeyiolatunji@yahoo.com², a08036002952@gmail.com ${ }^{3}$, \\ hieu.vm@vlu.edu.vn $\left.{ }^{4}\right\}$ \\ Business School, Horizons University Paris, France \\ Department of Financial Technologies, South Ural State University Chelyabinsk, Russia ${ }^{1}$, College of \\ Insurance and Financial Management Lagos Nigeria ${ }^{2}$, Lead City University Ibadan Nigeria ${ }^{3}$, \\ (Corresponding author) Faculty of Business Administration, Van Lang University, Vietnam. ${ }^{4}$
}

\begin{abstract}
Entrepreneurship is often considered a male-gendered concept and carries masculine connotations. However, the importance of women entrepreneurs and their contribution to the economy has recently been realized. Over the years women are seen in Nigeria business ecosystem as an unequal gender coupled with the cultural heritage of Nigeria where each woman is expected to be submissive. Women entrepreneurs struggle with gender discrimination, financial constraints, work-family conflict, lack of infrastructural support, unfavourable business and political environments, lack of entrepreneurship education, and personality-related barriers. These obstacles negatively impact the profitability, growth and survival of women-owned businesses. Our paper provides insights into the drivers, barriers and strategies women entrepreneurs adapt to survive and grow their businesses. To achieve this goal, an unstructured questionnaire was employed to elicit information from participants. This study informs entrepreneurs, policymakers and the research community of the survival strategies adopted by women entrepreneurs in Nigeria to deal with the challenges they are facing.
\end{abstract}

Keywords: Entrepreneurship education, financial constraints, gender discrimination, Women entrepreneurs, work-family conflict.

\section{Introduction}

Entrepreneurial activities support the survival and growth of business ventures (Nwachukwu, Chládková \& Zufan, 2017). Entrepreneurship is the process of creating, organising and running a business enterprise for profit or non-profit reason. Entrepreneurship is an instrument for improving the quality of life for families and communities and for achieving economic and environmental sustainability. Entrepreneurship involves thinking of new ways to solve problems and create value. It is characterised by innovation, proactiveness and risk-taking (Covin \& Slevin, 1989; Miller, 1983). Women entrepreneurship is a growing phenomenon (Martinez \& Marlow, 2017; Zahra \& Wright, 2016), which promote economic growth, creates jobs (Global Entrepreneurship Monitor Report, 2017) and improve quality of life (Orhan \& Scott, 2001; McMullan \& Warnice, 2016). Yet, the literature on women entrepreneurship and institutions is still fragmented (Giménez \& Calabrò, 2018; Jennings \& Brush, 2013). Their talents and potential have not been fully explored in developing countries due to economic and socio-cultural complexities (Jamali, 2009). Nonetheless, understanding 
the role of the institutional environment and gender is fast emerging in the literature (Yunis et al., 2019) which offers a strong theoretical foundation for examining women-owned enterprises. The literature on the contextual environment for entrepreneurship is not fully established (De Bruin et al., 2007; Dvouletý et al., 2018), which limits the understanding of the phenomenon. (Paul et al., 2017). Women entrepreneurs are successful in creating and managing small business ventures (e.g., Stevenson \& St-Onge 2011). Prior studies have examined the challenges encountered by women entrepreneurs in Africa (e.g., Aladejebi, 2020) and elsewhere (e.g., Terjesen \& Elam, 2012; Thébaud, 2015). These studies demonstrated that limited access to finance, human capital development opportunities, discrimination and social constraints, restrictions in decision making, conflicts between work and family life, handling patriarchal societies and gender discrimination hinders women entrepreneurship. It is important to understand gender in the context of entrepreneurship, particularly to identify the constraints, drivers and coping strategies employed by women micro-entrepreneurs. The economic participation of women is crucial in achieving a competitive environment to enable shared prosperity. We argue that it is important to explore the social constructions of gender in entrepreneurship, yielding new insights into the theory and perspectives of entrepreneurship. This is necessary to understand women entrepreneurial behaviour and their struggle to survive, such as how they respond to entrepreneurial constraints. The dynamic business environment in the West African region in general and Nigeria in particular, is pushing entrepreneurs especially women to search for how to remain competitive and survive in the marketplace. The competitive strategies are essential for all visionary women entrepreneurs of the twenty-first century. This paper offers insights into how various women entrepreneurs managed to adapt to the Nigerian business environment. Specifically, we contribute to gender and entrepreneurship literature by providing evidence on the obstacles, enablers and survival strategies of women micro-entrepreneurs in the emerging market context.

\section{Literature review}

\section{Theoretical framework}

Entrepreneurs act within a context determined by formal and informal rules. These rules can either enable or hinder entrepreneurship (Yunis et al., 2019). The feminist theory describes the "position" role of women in society. This theory is appropriate to understand the gendering of social entrepreneurship. We emphasize how gendering is perceived, and how it affects entrepreneurial behaviour. Institutional theory has been used to explain how entrepreneurs are hindered and enabled by the environment in which they live and work (Scott, 2008; Bruton \& Ahlstrom, 2010). Feminism suggests that gender is not limited to women or femaleness (Hanson, 1992), but how gender is institutionalised. Arguably, the understanding of gender provides important insights into entrepreneurship research and practice (Henry et al., 2016; Stead, 2017).

\section{Women entrepreneurship in Nigeria}

Women in traditional Nigerian culture are considered homemakers and custodians of family honour. The societal norms and conservative practices are widespread. The social setting is often affected by tribal trends that promote patriarchal culture, thus ensuring women are structurally under men. These cultural norms give men control of women's lives, so that 
gender forms an organising principle for society. The fact that women's social environment has a significant influence on their entrepreneurial activities present additional barriers for women entrepreneurs. Fielden and Davidson (2005) contend that family issues may hinder women entrepreneur's success. This remains the greatest challenge, particularly for women in a patriarchal society like Nigeria. The presence of women entrepreneur continues to be felt in every sector in Nigeria. Mahadeo, Dusoye and Aujayeb-Rogbeer (2015) observed that the case of disparity between men and women entrepreneurship was pronounced. Challenges faced by women entrepreneurs depend on sector, location and business model. It has been argued that women tend to be more in a disadvantaged position due to discriminatory sociocultural norm which sees them as wives and mothers (Adesua-Lincoln, 2012). Women entrepreneurs tend to have lower levels of financial capital than men entrepreneurs, raise smaller amounts of capital in both debt and equity, and rely on the internal source of financing (family, friend and personal savings) (Adesua-Lincoln, 2012). In Nigeria, women-owned businesses are not economically developed compared to that of men (Ekpe, Alabo \& Egbe, 2014). This is due to institutional barriers which do not allow women to fully take part in economic empowerment programmes (Ekpe et al., 2014). Women are considered to have strongly connected to the family, and most work of maintaining the house is assigned to them (Motilewa, Onakoya \& Oke, 2015). The generalisation of 'gender' in Nigerian suggest that women are not supposed to engage in stressful and high risk-taking ventures. This has discouraged many Nigerian women from developing, running, and growing successful business ventures. Aladejebi (2020) observes that widespread bias about social discrimination is not the main barriers women entrepreneurs encounter in South-West Nigeria. She concluded that lack of adequate training, access to start-up capital, and poor family support (including spousal support) hampers the growth of women entrepreneurship.

\section{Method}

This study employs a "Mixed Method Research (MMR)" approach (a combination of qualitative and quantitative approaches) (Schoonenboom \& Johnson, 2017) in the identification of obstacles, enablers and coping strategies of women micro-entrepreneurs in Oyo State South-West Nigeria. For this study, the qualitative technique was adopted as the main method and is complemented by the quantitative method.

\subsection{Design and instrument}

This study utilises a phenomenological technique for qualitative analysis and a descriptive method for quantitative analysis. The choice of the phenomenological method is due to the intention of the researchers to draw out the experiences of women micro-entrepreneurs within the Nigerian business environment. Phenomenological qualitative research design is characterised by an expression of live experiences by subjects within a survey (Neubauer et al., 2019). The challenges of women entrepreneurs have been a continuous occurrence, hence, its adoption within the current study. Within the framework of phenomenological qualitative research design, the current study adopts qualitative content analysis which involved coding of spoken words. It is a research technique based on the interpretation of written data content and personal influences using the specified classification procedure of coding and style recognition (Hsieh \& Shannon, 2005). As a research instrument, an open-ended interview form comprising of comprised 16 questions was used. The form is divided into two sections, A and 
B. Section A contains 7 questions that sought demographic information of participants, while section B contains questions on the entrepreneurial experiences of the women.

\subsection{Sample and data collection}

Data colle

ction took between September to December 2020 employing the purposive sampling technique. A Purposive sampling method allows a researcher to select respondents who can provide reliable information on the phenomenon under study (Silverman \& Marvasti, 2008). Our sample consists of 15 women who are small scale, micro-entrepreneurs. Data collection per participant lasted for 20 minutes and commenced with an introduction of the participant. Participants were informed about the confidentiality clause that comes with the provision of relevant information. This was necessary for the ethical considerations of the research.

\section{Results}

\subsection{Quantitative aspects: descriptive statistics}

In this section, we analyse field data using bar charts and simple frequency tables showing percentages, where necessary. Figure 1 shows the descriptive analysis of women entrepreneurs by age based on data gathered for the current study. The figure shows that women between ages 30-39 contribute to approximately $53 \%$ of surveyed participants, representing the largest part of the sample.

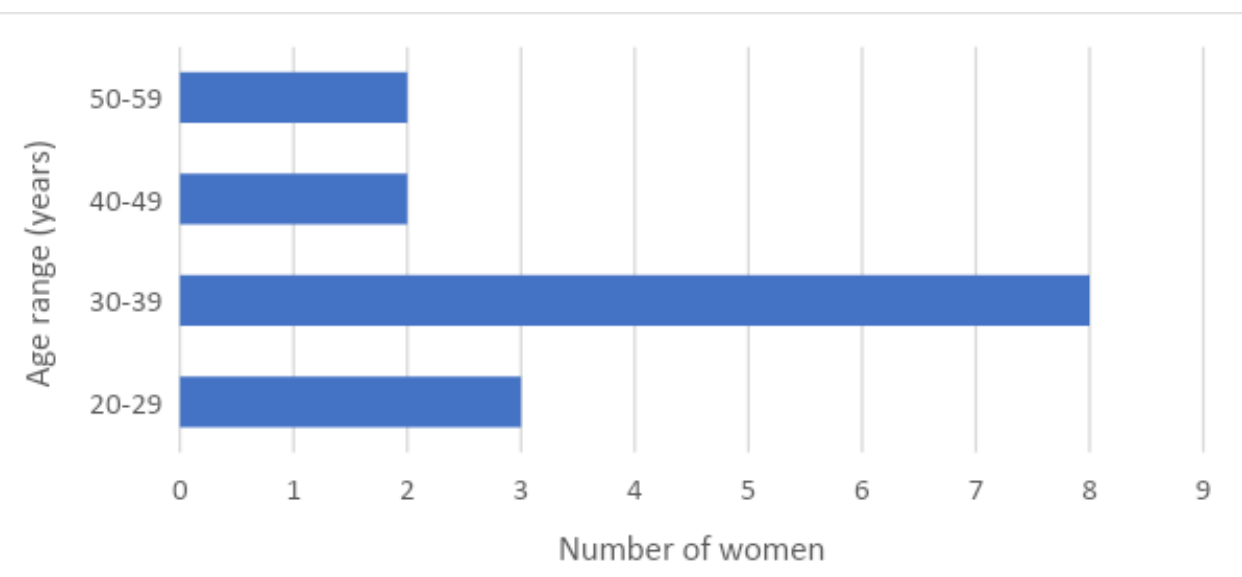

Figure 1. Descriptive statistics of female entrepreneurs by age

With regards to marital status, $60 \%$ of participants are married women who have ventured into entrepreneurship business to provide additional support for themselves and their homes. The horizontal bar chart in Figure 2 shows this information as well as the percentage of unmarried ladies (33.3\%) who also manage micro-enterprises. 


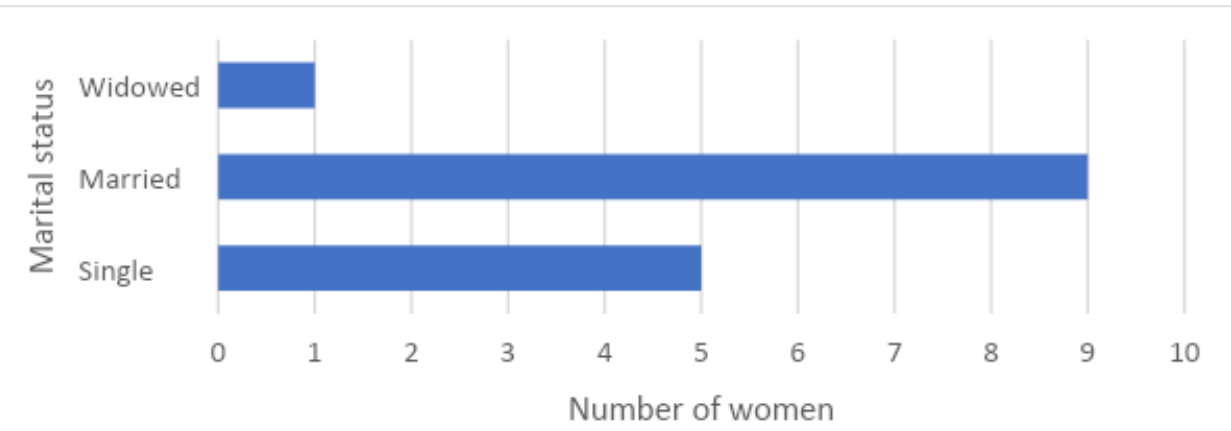

Figure 2. Descriptive statistics of female entrepreneurs by marital status

Data analysis for the current study as shown in table 1 reveals that the average women entrepreneur is educated for up to first grade. More than $35 \%$ have received national diplomas in comparison to $33.3 \%$ who have first degrees. In the same vein, one respondent was found to have a master's degree in business administration. This result suggests that women entrepreneurs are educated and knowledgeable.

Table 1. Educational level of female entrepreneurs

\begin{tabular}{|l|l|l|}
\hline Level & Frequency & Percentage (\%) \\
\hline Primary & 1 & 6.7 \\
\hline Secondary & 2 & 13.3 \\
\hline NCE/OND & 6 & 40 \\
\hline Bachelor/HND & 5 & 33.3 \\
\hline Masters & 1 & 6.7 \\
\hline Total & $\mathbf{1 5}$ & $\mathbf{1 0 0}$ \\
\hline
\end{tabular}

Figure 3 shows that women mostly use their personal savings as capital for entrepreneurship business. In the same vein, support from friends and family as well as a few bank loans are also reported.

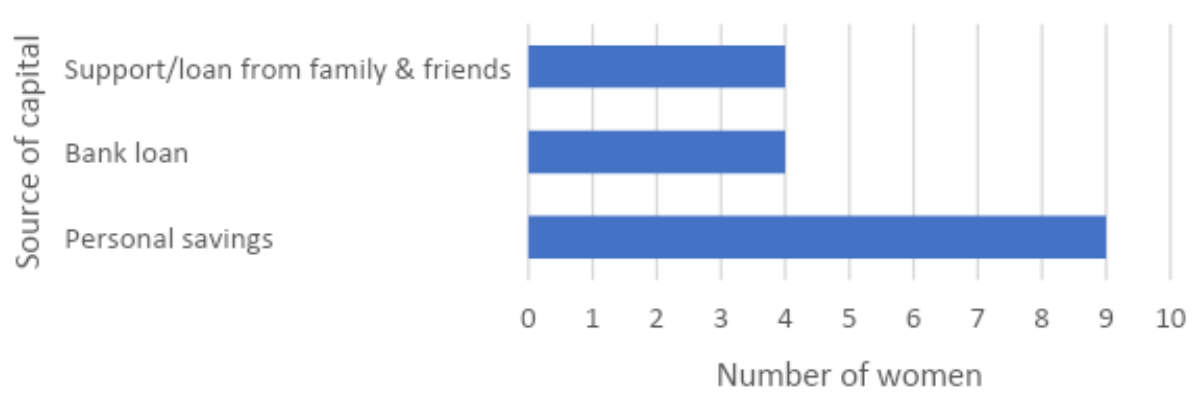

Figure 3. Source of capital of female entrepreneurs

With regards to the type of business amongst the women, it was observed that provision stores and supermarkets were the most common. Women who sold foodstuffs and frozen foods were also well represented. Other business areas include piggery (agriculture), hairdressing, sales of shoes and clothes, electronics and building materials, as well as small restaurants. 


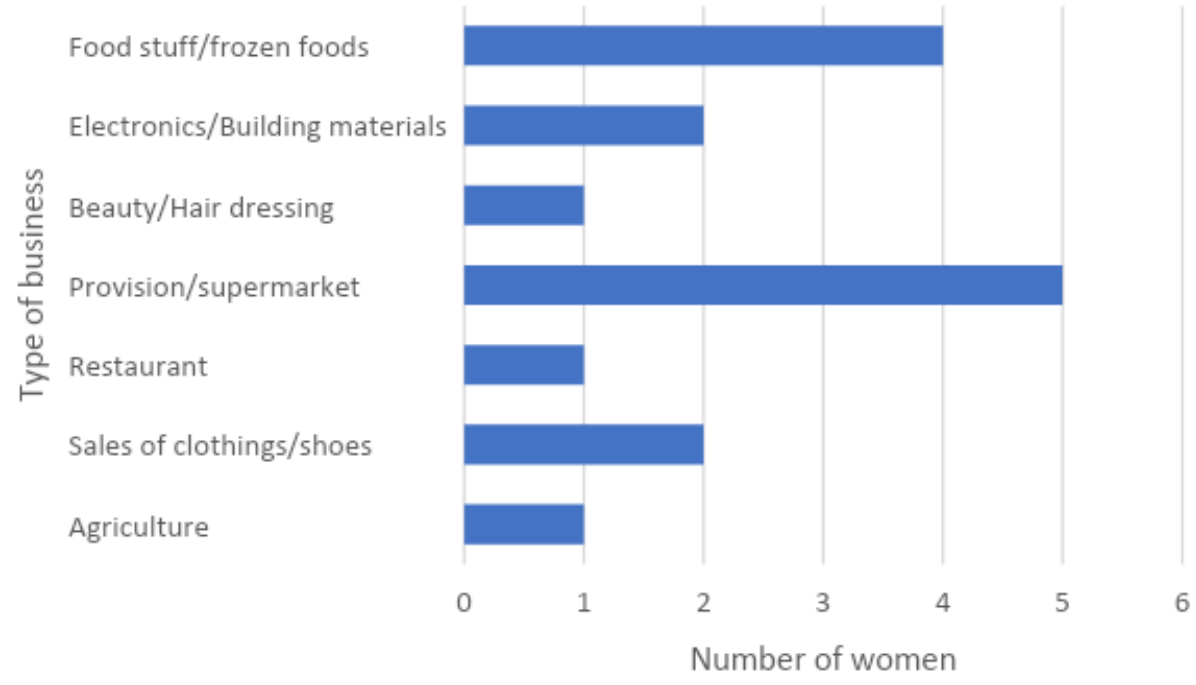

Figure 4: Types of business amongst surveyed female entrepreneurs.

With regards to whether or not women entrepreneurial businesses have been registered with Nigeria's Corporate Affairs Commission (CAC). Table 2 shows that only 40\% of participants are yet to get their business registered.

Table 2. Entrepreneurship business registration

\begin{tabular}{|l|l|l|}
\hline Registration & Frequency & Percentage (\%) \\
\hline Registered & 9 & 60 \\
\hline Unregistered & 6 & 40 \\
\hline Total & $\mathbf{1 5}$ & $\mathbf{1 0 0}$ \\
\hline
\end{tabular}

Table 3 shows how long surveyed women entrepreneurs have been in business. More than half have only been in business a few years. Whereas at least $20 \%$ have been in business for over a decade.

Table 3. Years of existence of business

\begin{tabular}{|l|l|l|}
\hline Period of operation (years) & Frequency & Percentage (\%) \\
\hline$<1-5$ & 8 & 53.3 \\
\hline $6-10$ & 4 & 26.7 \\
\hline $11-15$ & 1 & 6.7 \\
\hline $16-20$ & - & - \\
\hline Above 20 & 2 & 13.3 \\
\hline Total & $\mathbf{1 5}$ & $\mathbf{1 0 0}$ \\
\hline
\end{tabular}

\subsection{Qualitative Aspects: Content Analysis}

Table 4 is the coded transcript for the current study. First, the researchers tried to look through the responses provided by participants to each of the questions. Responses were then grouped logically to provide a first impression of the overall idea of the questions/answers. Next, researchers followed a careful re-reading of the responses as transcribed from the recording device, this preceded the design of a code book. The codes were written out depending on the relationship existing between responses provided to each question by the 
participants. When asked about the concept of entrepreneurship, many women entrepreneurs seem to demonstrate a clear understanding of its meaning without mincing words. Furthermore, it was observed many of the women entrepreneurs have mostly attained entrepreneurial skills from family businesses or apprenticeship programs. A few respondents also attended business schools where the knowledge of entrepreneurship was imbibed. Entrepreneurs need skills and knowledge to achieve success. As such, financial and economic knowhow are important competencies that can enable entrepreneurs, especially women micro-entrepreneurs to improve profitability (Vu \& Nwachukwu, 2021).

Table 4. Coding of responses provided by female entrepreneurs

\begin{tabular}{|c|c|c|c|}
\hline $\mathrm{S} / \mathrm{N}$ & Question & Responses & Code \\
\hline 1. & $\begin{array}{l}\text { Meaning of } \\
\text { entrepreneurship }\end{array}$ & Personal business ownership & Basic understanding \\
\hline 2. & $\begin{array}{lr}\text { Mode } & \text { of } \\
\text { entrepreneurial } & \text { skill } \\
\text { acquisition } & \end{array}$ & $\begin{array}{l}\text { Learning via apprenticeship, family } \\
\text { businesses, and business schools }\end{array}$ & Training avenues \\
\hline 3. & $\begin{array}{ll}\text { Motivation } & \text { for } \\
\text { entrepreneurship }\end{array}$ & Ability to meet personal needs & $\begin{array}{l}\text { Financial security } \\
\text { and Independence }\end{array}$ \\
\hline 4. & $\begin{array}{l}\text { Entrepreneurial } \\
\text { challenges }\end{array}$ & $\begin{array}{l}\text { Running capital and irregular power } \\
\text { supply }\end{array}$ & $\begin{array}{l}\text { Paucity of Funds } \\
\text { and infrastructural } \\
\text { deficit }\end{array}$ \\
\hline 5. & $\begin{array}{l}\text { Reason(s) } \\
\text { entrepreneurial } \\
\text { challenges }\end{array}$ & $\begin{array}{l}\text { Inaccessibility to bank loans; } \\
\text { economic challenges exacerbated by } \\
\text { pandemic; laissez faire attitude by } \\
\text { government }\end{array}$ & $\begin{array}{lr}\text { Lack } & \text { of } \\
\text { opportunities } & \text { for } \\
\text { business growth } & \end{array}$ \\
\hline 6. & $\begin{array}{l}\text { Strategy(ies) to surpass } \\
\text { challenges }\end{array}$ & $\begin{array}{l}\text { Sourcing for alternative loan routes } \\
\text { Customer service } \\
\text { Credit sales }\end{array}$ & Resilience \\
\hline 7. & $\begin{array}{lr}\text { Impact of } & \text { adopted } \\
\text { strategy(ies) } & \text { on } \\
\text { business } & \\
\end{array}$ & $\begin{array}{l}\text { Mostly negative, clumsy process by } \\
\text { microfinance banks for little amount } \\
\text { of money }\end{array}$ & $\begin{array}{l}\text { Frustration funding } \\
\text { processes }\end{array}$ \\
\hline 8. & $\begin{array}{l}\text { Common barriers of } \\
\text { female entrepreneurs }\end{array}$ & $\begin{array}{l}\text { Spouse unwillingness to help in } \\
\text { chores and care of children }\end{array}$ & Family structure \\
\hline 9. & $\begin{array}{l}\text { Impact of barriers on } \\
\text { entrepreneurial } \\
\text { abilities }\end{array}$ & $\begin{array}{llll}\text { Hindering } & \text { business } & \text { growth and } \\
\text { expansion } & & & \\
\end{array}$ & $\begin{array}{l}\text { Inability to fulfil } \\
\text { business potentials }\end{array}$ \\
\hline
\end{tabular}

All these training avenues ensured that participants are sufficiently skilled to succeed as entrepreneurs. It was important for many women to embrace entrepreneurship to gain financial freedom and some level of independence from spouses. This seemed like the most common motivation amongst the women for starting their businesses. Concerning the challenges faced, the paucity of funds was the main problem, and many women entrepreneurs hold the opinion that the availability of funds would have a positive impact on how much their businesses could grow. Furthermore, some of the participants who are into sales of frozen foods stressed the need for constant power supply. This is where the role of government is crucial, as infrastructural deficits would imply that there are little or no opportunities to grow. Notwithstanding the regular negative responses when they apply for loans, many of the women entrepreneurs continue to demonstrate resilience by seeking alternative routes to 
securing loans. Some of the women explained that micro-finance banks are sometimes helpful, but that the process to secure very little amounts of money can be frustrating. There were also discussions around very high-interest rates charged by some of these banks. Overall, women entrepreneurs face competition for sales from their male counterparts and are mostly disadvantaged as some spouses do not support the businesses of their wives. All of these challenges hinder women entrepreneurs from fulfilling their business potentials.

\section{Discussion of Results}

Coded results in table 4 show several discouraging situations faced by women who have taken up entrepreneurial roles. Notwithstanding there are few positives that can be derived from opinions provided by women entrepreneurs. When asked about the challenges faced by women entrepreneurship, and the steps so far taken to surpass these challenges, one respondent stated that:

"I don't have adequate funds to support expansion, however, I'm being creative/innovative with the small funds I have so that my business can grow".

This implies that although finances remain a major barrier to the success of women entrepreneurship, innovativeness in business can help women grow as it can be adopted as a survival strategy. A typical way for a small business to innovate is for entrepreneurs to learn from the experiences, successes, and failures of other businesses (Akinwale et al., 2017). This is related to the adoption of outside knowledge to grow and is commonly referred to as "open innovation" (Akinwale, 2018). Organisations need to create and renew their capabilities (Nwachukwu \& Vu, 2020) and find new ways to deliver their products and services to remain competitive (Nwachukwu, Zufan \& Chládková, 2020). Another woman, a frozen food seller, lamented that:

"Lack of regular power supply is the main problem for my business, even if I get a loan today, will I use all to buy fuel to power generator? 'Buying fuel to power generator will have a negative impact on my business".

The above response shows another barrier to the sustainability of women entrepreneurial businesses. The impact of infrastructural deficit on entrepreneurship businesses (e.g., Obokoh \& Goldman, 2016) is well documented in the Nigerian business literature. This affects all businesses, whether controlled by a woman or not. The government's attitude towards the funding of small-scale business in Nigeria, especially those run by women has not been encouraging. Similar to the provision of infrastructure, many of the women noted that the government is not doing enough to help them. Although there are quite a few structures in place to help SMEs, their effect has not been felt (Oboh \& Nwachukwu, 2018). In many cases, the loans available are insignificant compared to the number of people that apply for them. As such, the government's negligence of entrepreneurial funding issue was greatly criticized by many participants.

Another identified barrier is the issue of family structure and how men support the businesses of their wives. One woman stated that: 
"My inability to travel far away to buy goods is affecting my business". My husband will not allow me to, because there'll be no one to take care of the children if I travel".

Women entrepreneurs are finding ways of coping with the barriers they are facing. One woman, a building materials seller stated that:

"I offer good customer service and sell on credit to encourage customers to buy from me" "Though selling on credit has its disadvantages; it is the method am using to survive".

Organisations need a robust strategy to deal with challenges posed by environmental dynamism and competition (Nwachukwu, Chládková \& Olatunji, 2018). Customer satisfaction is essential to sustain customer loyalty (Deng et al., 2009; Nwachukwu \& Zufan, 2017; Sabir et al., 2014) to survive in the marketplace. Given that, a satisfied customer will make repeated purchases and inform other customers about a firm's product/service. It is important to note that a poorly managed customer experience may lead to loss of patronage and revenue. From the forgone responses by some entrepreneurial businesswomen in Nigeria, this study developed themes that address the research objectives. Figure 5 shows the grouping of enablers, barriers, and coping strategies employed by women-owned micro entreprises. The figure reveals that there are more barriers than enablers to the success of women-owned micro entreprises in Nigeria.

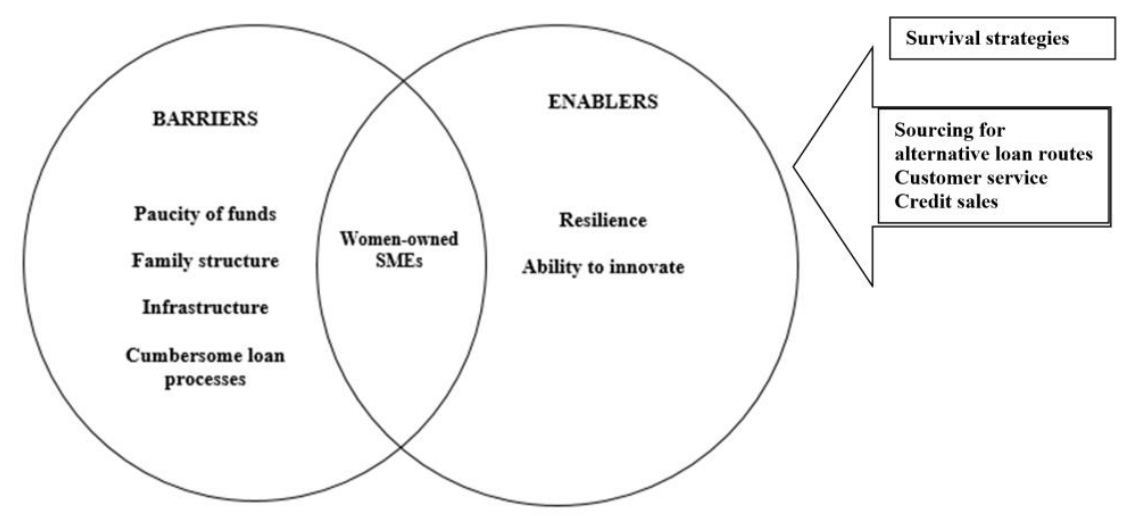

Figure 5. Themes derived for the study.

\section{Conclusions}

The survival of women-owned businesses has important implications for sustaining efforts made in advancing women's economic empowerment and gender equality across the world. This study has presented insight into gender and the gendering of women's entrepreneurship in the emerging market context. We capture the interpretive accounts of the challenges, enablers and coping strategies adopted by women micro-entrepreneurs. The findings suggest that paucity of funds was the main problem, and many women entrepreneurs hold the opinion that availability of funds would have a positive impact on how much their businesses could grow. Family structure, inadequate infrastructure and cumbersome loan processes present some challenges for women micro-entrepreneurs. Women entrepreneurs 
tend to be more concerned with balancing work and family, thus, deliberately choosing to keep their businesses small and easily controllable. Resilience and the ability to innovate is are important enablers for women entrepreneurs, even when they do not have access to enough funding opportunities. Creative education and training can foster women entrepreneurs' creativity (Vu \& Nwachukwu, 2020). Further, sourcing for alternative loan routes, customer service and credit sales are survival strategies employed by women micro-entrepreneurs. This study shed light on the experiences of women entrepreneur in Oyo State Nigeria, their constraints, motivations and survival strategies, contributing to gender and entrepreneurship literature in the developing country context. We, therefore, recommend that.

1. Government must provide adequate infrastructure to support women microentrepreneurs

2. Lending institutions should make it easy for women micro-entrepreneurs to assess loans for their businesses

3. Government agencies for example Small and Medium Enterprises Development Agency (SMEDAN) must ensure that loans are granted according to laid down rules.

4. Women micro-entrepreneurs should register their businesses with the Corporate Affairs Commission and other relevant government agencies as this can facilitate easy access to funding and support.

The present study has some shortcoming. This research uses a qualitative and descriptive approach, with a non-probability sample which somewhat limits its generalisability beyond this context. Nonetheless, this study adds to the debate on gender and entrepreneurship in the developing economies setting.

\section{Declaration of Conflicting Interests}

The authors declare no potential conflicts of interest with respect to the research, authorship, and/or publication of this article.

\section{Funding}

The authors receive no financial support for the research, authorship, and/or publication of this article.

\section{References:}

[1] Adesua-Lincoln, A. (2012). Prospects and Challenges of Women Entrepreneurs in Nigeria SSRN: https://ssrn.com/abstract=2181943 or http://dx.doi.org/10.2139/ssrn.2181943

[2] Akinwale, Y.O. (2018). Empirical analysis of inbound open innovation and small and mediumsized enterprises' performance: Evidence from oil and gas industry. South African Journal of Economic and Management Sciences, 21(1),1-9.

[3] Akinwale, Y., Adepoju, A \& Olomu, M., (2017). The impact of technological innovation on SMEs profitability in Nigeria. International Journal of Research, Innovation and Commercialization, 1(1), 74-92.

[4] Aladejebi, O. (2020). 21st Century Challenges Confronting Women Entrepreneurs in Southwest Nigeria. Archives of Business Research, 8(3), 261-280.

[5] Bokoh, L.O. \& Goldman, G. (2016). Infrastructure deficiency and the performance of smalland medium-sized enterprises in Nigeria's Liberalised Economy. Acta Commer., 16(1), 1-10.

[6] Bruton, G.D., Ahlstrom, D \& Li, H.L. (2010). Institutional theory and entrepreneurship: Where are we now and where do we need to move in the future? Entrep. Theory Pract. 34, 421-440.

[7] Covin, J.G. \& Slevin, D.P. (1989). Strategic management of small firms in hostile and benign environments. Strategic Management Journal 10, 75-87. 
[8] De Bruin, A., Brush, C.G. and Welter, F. (2007). Advancing a framework for coherent research on women's entrepreneurship. Entrep. Theory Pract. 31, 323-339.

[9] Deng, Z., Lu, Y., Wei, K.K \& Zhang, J. (2009). Understanding customer satisfaction and loyalty: An empirical study of mobile instant messages in China. International Journal of Information Management, 30(4), 289-300.

[10] Dvouletý, O., Gordievskaya, A. \& Procházka, D.A. (2018). Investigating the relationship between entrepreneurship and regional development: Case of developing countries. J. Glob. Entrep. Res., 8-16. https://doi.org/10.1186/s40497-018-0103-9

[11] Ekpe, D.E., Alabo, E \& Egbe, I.J. (2014). Women, gender equality in Nigeria: A critical analysis of socioeconomic and political (gender issues). Journal Research in Peace Gender and Development, 4(1), 15-20.

[12] Ekpe, D.E., Alabo, E \& Egbe, I.J. (2014). Women, gender equality in Nigeria: A critical analysis of socioeconomic and political (gender issues). Journal Research in Peace Gender and Development, 4(1), 15-20.

[13] Fielden, S.L \& Davidson, J.M. (2005). The way forward for women small business owners', in Fielden, S. L. and Davidson, J. M. (Eds.): International Handbook of Women and Small Business Entrepreneurship. Cheltenham: Edward Elgar Publishing Limited.

[14] Giménez, D. \& Calabrò, A. (2018). The salient role of institutions in Women's entrepreneurship: A critical review and agenda for future research. Int. Entrep. Manag. J. 14, 857-882.

[15] Global Entrepreneurship Research Association (GERAI. 12017). Global entrepreneurship monitor Global report 2016/17. Available from https://www.gemconsortium.org/report.

[16] Hanson, S. (1992). Geography and feminism: Worlds in collision? Ann. Assoc. Am. Geogr. $82,569-586$.

[17] Henry, C., Foss, L \& Ahl, H. (2016). Gender and entrepreneurship research: A review of methodological approaches. Int. Small Bus. J., 34, 217-241.

[18] Hsieh, H.F. \& Shannon S.E. (2005). Three approaches to qualitative content analysis. Qual Health Res., 15(9), 1277-88.

[19] Jamali, D. (2009). Constraints and opportunities facing women entrepreneurs in developing countries: A relational perspective. Gend. Manag. Int. J., 24, 232-251.

[20] Jennings, J.E. \& Brush, C.G. (2013). Research on women entrepreneurs: Challenges to (and from) the broader entrepreneurship literature? Acad. Manag. Ann., 7, 663-715.

[21] Mahadeo, J.D., Dusoye, I.C. \& Aujayeb-Rogbeer, A. (2015). Women and entrepreneurship: an alluring or luring option. Int. J. Entrepreneurship and Small Business, 25(3), 351-374.

[22] Martinez Dy, A. \& Marlow, S. (2017). Women Entrepreneurs and Their Ventures: Complicating Categories and Contextualising Gender. London, UK: Routledge

[23] McMullen, J.S. \& Warnick, B.J. (2016). Should we require every new venture to be a hybrid organization? J. Manag. Stud. 53, 630-662.

[24] Miller, D. (1983). The correlates of entrepreneurship in three types of firms. Management Science 29, 770-791.

[25] Motilewa, B.D., Onakoya, O. \& Oke, A.D. (2015). ICT and gender specific challenges faced by female entrepreneurs in Nigeria. International Journal of Business and Social Science, 6(3), 97-105.

[26] Neubauer, B.E., Witkop, C.T. \& Varpio, L. (2019). How phenomenology can help us learn from the experiences of others. Perspect Med Educ. 8, 90-97.

[27] Nwachukwu, C \& Vu, M.H. (2020). Strategic flexibility, strategic leadership and business sustainability nexus. International Journal of Business Environment, 11(2), 125-143.

[28] Nwachukwu, C \& Žufan, P. (2017). Influence of Customer focused Mission statement on Customer Satisfaction. Acta Universitatis Agriculturae et Silviculturae Mendelianae Brunensis, 65(3), 1031-1038.

[29] Nwachukwu, C., Chládková, H. \& Olatunji, F. (2018). Strategy formulation process and innovation performance nexus. International Journal for Quality Research, 12(1), 147-164. 
[30] Nwachukwu, C., Chládková, H., \& Žufan, P. (2017). The relationship between entrepreneurial orientation, entrepreneurial competencies, entrepreneurial leadership and firm performance: A proposed model. Business Trends, 7(1), 3-16

[31] Nwachukwu, C., Žufan, P. \& Chládková, H. (2020). Employee commitment to strategy implementation and strategic performance: organisational policy as moderator. International Journal of Business Excellence, 20(3), 398-418

[32] Oboh, I. \& Nwachukwu, C.E. (2018). Entrepreneurial support in Nigeria: A review paper. Management Strategies, 2(40), 45-51.

[33] Orhan, M. \& Scott, D. (2001). Why women enter into entrepreneurship: An explanatory model. Women Manag. Rev. 16, 232-247.

[34] Paul, J.; Hermel, P. \& Srivatava, A. (2017). Entrepreneurial intentions-Theory and evidence from Asia, America, and Europe. J. Int. Entrep. 15, 324-351.

[35] Sabir, R., Ghafoor, O., Hafeez, I., Akhtar, N. \& Rehman, A. (2014). Factors affecting Customer Satisfaction in Restaurants industry in Pakistan. International review of Management and Business Research, 3(2), $869-876$.

[36] Schaupp, L.C. \& Belanger, F. (2016). Social commerce benefits for small businesses: An organizational level study. Journal of Organizational and End User Computing (JOEUC), 28(3), 49-66.

[37] Schoonenboom, J. \& R. Burke J. (2017). How to Construct a Mixed Methods. Research Design. Köln Z Soziol (Suppl 2)69, 107-131.

[38] Scott, W. (2008). Approaching Adulthood: The Maturing of Institutional Theory. Theory and Society, 37(5), 427-442.

[39] Silverman, D \& Marvasti, A. (2008). Doing Qualitative Research: A Comprehensive Guide. Thousand Oaks, CA, USA: Sage.

[40] Stead, V. (2017). Belonging and women entrepreneurs: Women's navigation of gendered assumptions in entrepreneurial practice. Int. Small Bus. J. 35, 61-77.

[41] Terjesen, S., \& Elam. A. (2012). Women Entrepreneurship: A Force for Growth. International Trade Forum. 2, 16-18.

[42] Thébaud, S. (2015). Business as plan B: institutional foundations of gender inequality in entrepreneurship across 24 industrialized countries. Administrative Science Quarterly, 60(4),671-711.

[43] Vu, H.M. \& Nwachukwu, C. (2020). Constraints and enablers to growth of female-owned businesses: empirical review. Proceedings of the 36th International Business Information Association (IBIMA), 5701-5708, 4-5 November 2020, Granada Spain.

[44] Vu, H.M. \& Nwachukwu, C. (2021). Influence of entrepreneur competencies on profitability and employee satisfaction. International Journal of Management and Enterprise Development, 20(1), 1-16.

[45] Yunis, M.S., Hashim, H. \& Anderson, A.R. (2019). Enablers and constraints of female entrepreneurship in Khyber Pukhtunkhawa, Pakistan: Institutional and Feminist Perspectives, Sustainability, 11(27), 1-20.

[46] Zahra, S.A. \& Wright, M. (2016). Understanding the social role of entrepreneurship. J. Manag. Stud. 53, 610-629. 